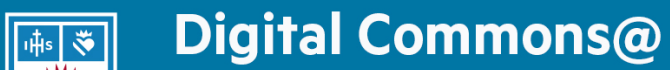

Loyola Marymount University

LMU Loyola Law School

Journal of Catholic Education

Volume 20 | Issue 1

Article 7

October 2016

\section{Losing My Religion? The Impact of Spiritual Cues on Noncognitive Skills}

Daniel H. Bowen

Rice University

Albert Cheng

University of Arkansas

Follow this and additional works at: https://digitalcommons.Imu.edu/ce

Part of the Behavioral Economics Commons, Education Policy Commons, Experimental Analysis of Behavior Commons, and the Social Psychology Commons

\section{Recommended Citation}

Bowen, D. H., \& Cheng, A. (2016). Losing My Religion? The Impact of Spiritual Cues on Noncognitive Skills. Journal of Catholic Education, 20 (1). http://dx.doi.org/10.15365/joce.2001072016

This Article is brought to you for free with open access by the School of Education at Digital Commons at Loyola Marymount University and Loyola Law School. It has been accepted for publication in Journal of Catholic Education by the journal's editorial board and has been published on the web by an authorized administrator of Digital Commons at Loyola Marymount University and Loyola Law School. For more information about Digital Commons, please contact digitalcommons@lmu.edu. To contact the editorial board of Journal of Catholic Education, please email JCE@nd.edu. 


\section{Losing My Religion? The Impact of Spiritual Cues on Noncognitive Skills}

\section{Cover Page Footnote}

We are very appreciative for the assistance and efforts of Corey Alderdice, Charlie Belin, Anna Egalite, Josiah Foster, Jay Greene. Anne Greenwood, Jennifer Hafer, Collinn Hitt, Brian Kisida, Jonathan Mills, and Kim Torres. We also would like to thank James Shuls for his helpful comments and discussions. 


\title{
Losing My Religion? The Impact of Spiritual Cues on Noncognitive Skills
}

\author{
Daniel H. Bowen, Rice University \\ Albert Cheng, University of Arkansas
}

Studies consistently show that Catholic schools produce positive impacts on educational outcomes. Many charter school networks in the United States now provide, what are essentially, secularized versions of the Catholic education model. However, charter schools cannot legally replicate the overt religious curriculum and mission of Catholic schools. Although difficult to disentangle its impacts from confounding variables, research suggests that religiosity is a positive predictor of educational outcomes. This relationship might suggest that religious-based education produces effects on outcomes of public value that could be difficult to replicate in secularized contexts. To examine this question we conducted an experiment where 180 secondary school students were randomly assigned to a priming task with religious, secularized, or neutral cues. We find that religious cues increase students' self-regulatory capacities, a predictor of educational attainment, and boost political tolerance. These findings provide preliminary evidence to suggest that religious-based education provides benefits that secularized equivalents cannot fully emulate.

Keywords: religious education, charter schools, school choice, noncognitive skills, civic education

$\mathrm{S}$ tudents attending private religious schools in the United States tend to exhibit higher levels of academic achievement than their public school counterparts (Jeynes, 2012). Catholic schools, in particular, have been very successful with improving students' educational outcomes, especially with historically underserved students (e.g., Altonji, Elder, \& Taber, 2005; Bryk, Lee, \& Holland, I993; Evans \& Schwab, I995; Grogger \& Neal, 200o; Hoffer, Greeley, \& Coleman, I985; Kim, 20II; Neal, I997; Sander \& Krautman, 1995). Scholars attribute these successes to various factors that are common to the U.S. Catholic education model. Examples include mission cohesion, successes with the development of social capital, stronger market pressures, high expectations for all students, and school autonomy (Chubb \& Moe, r988; Coleman \& Hoffer, I987; Meyer, 2007). However, the independent role and value of having a

Journal of Catholic Education, Vol. 20, No. I, October 2016, 152-176. This article is licensed under a Creative Commons Attribution 3.0 International License. doi: ro.15365/joce.2001072016 
student's education occur within an explicitly religious learning environment and its impact on outcomes of public value is rarely given consideration (Bryk et al., I993).

Assessing these impacts could have meaningful implications for policy decisions pertaining to school choice regulations and restrictions. Over the past half century, Catholic schools in the U.S. have experienced sharp declines in student enrollments, leading to thousands of school closures (Meyer, 2007). Given their successes, this trend could be worrisome (Brinig \& Garnett, 20I4; Finn \& Smarick, 2009). However, many charter school networks have imitated many of the core aspects of Catholic schools, with the exception of having an explicitly religious mission, curricula, and practices, in hopes of replicating their successes (Kennedy, 20I2; Whitman, 2008). Consequently, charter schools have provided, to an extent, secularized versions of Catholic schools with the advantage of serving as a "free" alternative to families in districts without robust voucher programs (McShane \& Kelly, 20I4). Therefore, with the possibility of charter schools producing the same, if not better, public benefits without the oversight of religious institutions, then it plausibly becomes easier to justify allocating public subsidies to charter schools (and, simultaneously, more challenging to justify making public subsidies available to religious schools) on the grounds of maintaining a strict separation of church and state.

It also becomes difficult to justify making subsidies available to Catholic and other religious schools if these schools somehow facilitate socially undesirable outcomes. There are deep-seated concerns amongst private school skeptics pertaining to the development of students' civic values, such as political tolerance (Godwin \& Kemerer, 2002). For instance, Gutmann (I995) has contended that "Any defensible standard of civic education must be committed to prepare children for the rights and responsibilities of citizenship even over the opposition of their parents" (p. 567). Conversely, should religiosity ${ }^{\mathrm{I}}$ have an independent, positive impact on such outcomes, then secularized school counterfactuals might not be able to replicate the successes of Catholic and other religious schools. Such schools may, therefore, warrant public subsidization (Boffetti, 200I).

$1 \quad$ We use the operational definition of "religiosity" as an individual's personal sense of private and public connection, engagement, and dedication to a particular religion (e.g., Erickson \& Phillips, 2012). 
While publicly-valued benefits of having students learn in religious settings are not as intuitive as many of the other staples of Catholic education (e.g., high standards, school autonomy, mission cohesion, etc.), there is research to suggest that religiosity independently boosts educational outcomes. Adolescents' religiosity is significantly, positively associated with educational attainment (Erickson \& Phillips, 2012). There is also a consistent, positive relationship between individuals' religiosity and capacity to exhibit self-regulation (McCullough \& Willoughby, 20o9). Some psychologists have maintained that this relationship stems from the fact that religion provides practitioners (i.e., individuals who are actively engaged in religious activities) with clear, consistent standards that improve and motivate self-regulatory behaviors (Geyer \& Baumeister, 2005; Öner-Özkan, 2007; Rachlin, 2000). However, even with non-practitioners, subtle cues that activate God concepts increase prosocial behaviors, suggesting that instilling a sense of having unseen thoughts and actions being monitored significantly affects conduct (Shariff \& Norenzayan, 2007). Collectively, these findings could imply that religious learning environments, instruction, and more regular, explicit practice increase self-regulatory capacities which subsequently increase the likelihood of academic accomplishments such as educational attainment.

It is difficult to determine the causal relationship between religion and educational outcomes. One challenge is that inherent selection is involved with school choices. In other words, students enrolled in religious schools are fundamentally different than those enrolled in secular schools in ways that reflect or lead to disparities in educational outcomes that should not necessarily be attributed to school sector choice. Ideally, a randomized controlled trial would make it possible to isolate the causal effects of faith-based schools. However, restrictions founded upon research ethics and feasibility prevents the possibility of conducting such an experiment. Moreover, even if school enrollments were determined more or less by chance, disentangling the independent religious effects from other aspects that are highly correlated with particular school models remains onerous (Wolf, 20I4).

We have attempted to circumvent these challenges and assess the independent impacts of religious cues in educational settings by conducting a laboratory experiment. In this study students were randomly assigned to a priming word scramble task with either religious, secularized, or neutral cues; this procedure has become a commonly applied research technique in the field of social psychology (Bargh \& Chartrand, 20I4). We then examined 
whether these different priming conditions produce short-term effects with I80 secondary school students in terms of self-regulatory capacity, a strong predictor of educational attainment, and political tolerance, an outcome that is plausibly negatively impacted by religious instruction. Specifically, after the word scramble priming task, students were asked to perform a self-regulatory-depleting, persistence task. After completing these tasks the participants answered questions regarding their political tolerance and then provided two options for how they preferred to be compensated for their participation. They could either accept immediate compensation or receive a marginally larger payment for opting to wait a week for their reward. By conducting such an experiment, our goal is to better determine whether there is indeed preliminary evidence that the regularly-induced, religious conceptualizations that are likely provided in faith-based learning environments play a substantial role in significantly impacting educational outcomes of public value.

The results of our experiment suggest that the regularly-primed conceptualizations that are provided in religious school settings indeed have independent, positive impacts on one's self-regulatory capacity and political tolerance. Specifically, students in this study who were randomly assigned to be primed with religious cues were twice as likely to defer gratification, relative to those in the control group, in terms of opting for the marginally higher, postponed payment for participation. Moreover, religiously-primed students were also more likely to defer gratification than those receiving secularized equivalents of the religious primes. Religiously primed students also demonstrated greater political tolerance than those receiving neutral primes; however, these students were no more tolerant than those receiving the secularized primes. Finally, students in all three conditions were no different in the extent to which they exhibited persistence in the regulatory-depletion task. Since participants were assigned by chance to the three experimental groups, we believe that these findings provide preliminary, causal evidence to suggest that at least part of the successes of Catholic (and, more broadly, religious) schools may be attributable to the presence of religious cues, the effects of which secularized replicas might not be able to emulate.

The remainder of the paper is divided into five sections. We begin by reviewing the literature on the effects of religiosity on self-regulatory behaviors and political tolerance. Next, we explain the methods used in conducting our experiment. We present and discuss our findings in the third and fourth sections and provide our conclusions in the final section. 


\section{Literature Review}

\section{Catholic Schools, Religion, and Educational Success}

Several studies have concluded that K-I2 Catholic schools produce significant, positive outcomes on various measures of success in education, especially for historically underserved students (Hoffer, 1997). Providing one of the earliest evaluations of Catholic school impacts on student outcomes, Coleman, Hoffer, and Kilgore (I98I) found that K-I2 Catholic schools produce higher cognitive achievement and develop greater educational aspirations. These findings were later corroborated by Bryk, Lee, and Holland's (I993) comprehensive study of Catholic high schools. More recent analyses have produced mixed findings with regard to Catholic school impacts on cognitive achievement but results tend to be more consistent, exhibiting substantial increases, with regard to students' likelihood of graduating high school and enrolling in college (Altonji et al., 2005; Eide, Goldhaber, \& Showalter, 2004; Evans \& Schwab, 1995; Figlio \& Stone, 200o; Grogger \& Neal, 2000; Kim, 20Ir; Neal, I997; Nguyen, Taylor, \& Bradley, 2006; Sander \& Krautman, 1995).

When comparing student performance across school sectors, researchers have tended to focus on differences between traditional public and private schools or traditional public schools and charter schools (Braun, Jenkins, \& Grigg, 2006; Center for Research on Education Outcomes, 2013). However, some evaluators have conducted analyses that potentially isolate sector effects by assessing differences between charter and private religious (Lubienski \& Lubienski, 2006; Scott, Rock, Pollack, \& Ingels, 1995), private religious and private secular (Gamoran, 1996; Kim \& Placier, 2004), and private religious and public magnet schools (Gamoran, 1996). Results from these studies have generally been mixed, with no conclusive trend with regard to plausible religious schooling effects. Moreover, a general concern with these studies is the likelihood of results being driven by an omitted variable bias that stems from the inability to control for unobserved student characteristics that are both highly correlated with school sector selection and predictive of student achievement.

Sociologists have investigated environmental factors that could explain what makes Catholic schools successful. Parochial schools tend to be successful because of their ability to cultivate social capital among parents, students, and school personnel (Coleman \& Hoffer, 1987). The production of social capital among Catholic school communities arises from their religiously- 
motivated mission to serve not only individual students but also the students' families and surrounding neighborhoods. In contrast, secular private schools may also cherish a sense of community but tend to lack many of the structured components of parochial schools (e.g., weekly gatherings for religious services that also serve as social events). This difference in social capital production opportunities might explain why Catholic schools have been more successful than nonreligious private schools at improving educational outcomes, particularly with underserved students coming from less-stable home environments (Bryk et al., 1993).

There are four foundational characteristics of Catholic schools that likely explain their effectiveness: "a delimited technical core, communal organization, decentralized governance, and an inspirational ideology" (Bryk et al., I993, p. 297). While concluding that these core foundational components could be implemented in public schools, the authors assert that, although unmeasured, the inherently religious aspects of Catholic education are vital:

To ignore the importance of ideology because it cannot be easily captured in statistical analyses or summarized with numbers would be a serious mistake. Statistical analyses can help us to see some things, but they can also blind us to the influence of factors that are beyond their current horizons. We believe that the true renewal of our educational institutions will require melding insights from scientific pursuit with inspiration from our evocative traditions. (p. 304)

In other words, the foundational characteristics which can be secularized are certainly salient to the success, but the power and influences of the religious component may produce unique effects that could prove impossible to legally imitate outside of a faith-based setting.

\section{Religiosity and Self-Regulation}

The ability to self-regulate - defined as "how a person exerts control over his or her own responses so as to pursue goals and live up to standards" has been found to be a significant predictor of academic achievement (Baumeister \& Vohs, 2004, p. 500). Students who are better equipped at developing future-time perspectives fare better in school (Baumeister \& Heatherton, 1996; Bembenutty \& Karabenick, 2004; Mischel, Shoda, \& Rodriguez, 1989). The positive relationships between self-regulation and educational attainment together with the Catholic school effect on high school graduation 
and college matriculation suggests that Catholic schools potentially increase students' academic attainment through the cultivation of increased self-regulatory capacity (Segal, 2008).

Social psychologists have investigated several mechanisms by which religious schools potentially improve students' self-regulatory capacities. From their review of the research on the relationship between religion and self-control, McCullough and Willoughby (2009) conclude that religious practices are routine exercises of self-regulatory processes and that long-term religious involvement leads to substantial increases in one's ability to exhibit self-regulatory strength and recovery. Geyer and Baumeister (2005) posit that religious practice and conceptualization improves self-regulation because it presents individuals with clear and consistent standards (see also Fishbach, Friedman, \& Kruglanski, 2003; Rachlin, 2000). Religion also provides individuals with strong motivations for adhering to set standards (Bering \& Johnson, 2005; Öner-Özkan, 2007; Shariff \& Norenzayan, 2007). In addition, religious practice facilitates frequent self-monitoring (e.g., habitual examination of conscience) (Carter, McCullough, \& Carver, 20I2).

However, research has also shown that it is possible to secularize particular mechanisms that facilitate altruistic behavior (e.g., evoking deference to moral authority with reminders of secularized justice systems and social contracts) (Shariff \& Norenzayan, 2007). Nonetheless, it is possible that secular mechanisms are not as effective as religious mechanisms at facilitating other self-regulatory skills such as delayed gratification or persistence, which play a stronger role than altruism in improving student outcomes such as educational attainment (see Almlund, Duckworth, Heckman, \& Kautz, 20II).

\section{Religiosity and Political Tolerance}

The religious component of schooling (i.e., the overtly religious references and practices that cannot be legally implemented in public education) may lead to self-regulatory and educational benefits, but it may coincidentally facilitate socially undesirable outcomes. Interculturalists, for example, worry that private, religious schools inhibit the development of political tolerance because individuals come to accept particular ideals with an unwillingness to consider alternative viewpoints (Gibson, 2010; Gradstein \& Justman, 2005; Nunn, Crockett, \& Williams, I978; Wilcox \& Jelen, I990).

Sullivan, Pierson, and Marcus (1982) have defined "political tolerance" as the "willingness to permit the expression of ideas or interests one opposes" (p. 2). As discussed earlier, religious schools are value communities that serve 
to reinforce shared beliefs. As such, religious school communities tend to be more homogenous relative to the populations within which they are established. Insofar as religious schools cultivate dogmatic students and ethnocentrism, they may propagate political intolerance (Eisenstein, 2008; Gibson, 2oro; Hall, Matz, \& Wood, 2oro; Sullivan et al., I982). In contrast, public, and even secular private schools ideally have more diverse enrollments, propagating lessons on coexisting with others and fostering social cohesion (Gutmann, I987; Macedo, 2003). However, it remains unclear how closely public and secular private schools embody this ideal.

Empirical evaluations of the claims regarding the connections between political tolerance and school sector have largely found evidence to the contrary. In a review of the literature, Wolf (2005) concluded that private school students, particularly those attending Catholic schools, exhibit greater tolerance than students in public schools. More recent studies have corroborated this conclusion (e.g., Cheng, 20I4; Fleming, Mitchell, \& McNally, 20I4). Catholic school students are more likely to form friendships with students of other racial and ethnic groups and less likely to engage in racial and ethnic conflicts (Greene, Mellow, \& Giammo, I999). However, private secular school students score significantly higher on a tolerance index than those attending non-Catholic religious schools (Campbell, 20oI). While this latter finding could indicate that religion deters tolerance, Campbell warns that students' index scores could reflect omitted variable biases that pertain to school selection and do not necessarily reflect a causal school-sector effect.

A plausible explanation for these potentially counterintuitive empirical findings is that spiritual and moral instruction fosters a strong sense of personal identity, which may enable students to develop more positive views of themselves. Developing a positive view of one's personal identity is a necessary precursor for developing positive views of others (Banks, 200I). Individuals who experience a higher degree of self-actualization tend to exhibit greater political tolerance (Sullivan et al., 1982). This relationship likely occurs because individuals with a stronger sense of self tend to be less threatened by others who may hold contrary worldviews. Therefore, religious schools have the potential to foster political tolerance by strengthening individuals' personal identity (Short, 2002). Moreover, religion can provide students with a coherent moral vision, which is necessary for moral formation, and foster dispositions consistent with tolerance (Bellah, Madsen, Sullivan, Swidler, \& Tipton, I985; Hunter, 200I). 


\section{The Effects of Religious Cues}

It is difficult to assess whether there is indeed a causal relationship with religion serving as a mechanism (occasionally referred to as a "moral compass") that can independently shape and influence human behavior and outcomes such as individuals' abilities to exhibit self-regulation and political tolerance. Researchers typically address this difficulty by implementing controlled experiments that account for confounding factors, but there is a tradeoff. Researchers must formalize and simplify abstract concepts — in this case, religion and religiosity - to test their effects in controlled settings (e.g., Djupe and Calfano, 2or2; Harrison \& McKay, 20I3; Johnson, Rowatt, \& LaBouff, 2010; Pichon et al., 2007; Shariff \& Norenzayan, 2007; Rounding, Lee, Jacobson, \& Ji, 20I2; Uhlmann, Poehlman, Tannenbaum, \& Bargh, 20II). We elaborate on the limitations of this approach in the discussion of our results. For now, we highlight prior work that has used religious cues to induce a sense of religiosity and to simulate the effects of religion.

Of particular relevance to the present study is Rounding et al. (20I2), who directly tested the hypothesis that religious cues independently strengthen the ability to delay gratification and persist through difficult scenarios.

Among a sample of undergraduate college students, they found that religious cues produce greater self-regulatory capacities and more effectively enable the replenishment of depleted self-regulatory capacities. Uhlmann et al., (2OII) similarly found that US adults primed with religious words exerted more effort on an anagram task than those who were primed with neutral words. However, Harrison and McKay (20I3) attempted to replicate the Rounding et al. (2OI2) study, using slightly different methods to measure delayed gratification, and found no significant effects among their own sample of postsecondary students.

Regarding tolerance, priming postsecondary students with subliminal Christian words appears to increase racial prejudice, even when controlling for participants' baseline religiosity (Johnson et al., 20Io). Conversely, Djupe and Calfano (2OI2) found there was no effect on tolerance when participants were cued with inclusive religious values that emphasize building bridges to others outside the group. Therefore, prior research suggests that religious cues seem to increase intolerance but only if the religious cues promoted exclusive values that reinforce in-group identity and association.

We take a similar approach in this present study to test whether religious conceptualizations affect self-regulation and tolerance. However, one significant difference with our study and those mentioned in this section is that our 
sample consisted of secondary, rather than postsecondary students. Therefore, it is plausible that these findings would not extrapolate to a younger population of student participants. We describe the procedures of our experiment in the next section.

\section{Methods}

\section{Participants and Procedures}

The participants for this study were $\mathrm{I} 8 \mathrm{O} \mathrm{II}^{\mathrm{th}}$ - and $\mathrm{I} 2$ th-grade students attending a public secondary boarding school in a southern U.S. state. Upon arrival to the laboratory, participants were randomly assigned to one of three treatment conditions: religious, secular, or neutral priming (control). To conceal the purpose of the study, we told participants that they were completing verbal skills exercises, but later informed participants of the intent of the study with a debriefing session. All participants, regardless of assigned condition, completed three tasks in the following order: (a) a priming task (sentence scramble), (b) an impossible task (anagrams), and (c) a general survey that included items to collect participants' responses on the political tolerance scale in addition to background demographics and measures testing the effectiveness of the priming task.

\section{Priming}

The purpose of priming in psychology experiments is to explore the “temporary activation states of an individual's mental representations and how these internal readinesses interact with environmental information to produce perceptions, evaluations, and even goal pursuits and social behavior" (Bargh \& Chartrand, 20I4, p. 3I6). As such, the technique for this study aimed to measure responses and behaviors that occur when experimentally activating adolescents' conceptualizations of religiousness. We administered a supraliminal, conceptual priming task for the purpose of inducing powerful manipulations while trying to ensure that participants remained unaware of the connection between the experimental tasks and the central hypotheses of the study (Bargh \& Chartrand, 2014).

We adopted our priming task from Shariff and Norenzayan (2007) and Toburen and Meier's (2010) experimental studies that examined the impacts of priming participants with God-related concepts on behavior. This priming task consisted of ten scrambled, five-word sentences. Participants were instructed to eliminate one and then rearrange the four remaining words to 
form a coherent sentence. There were three versions of this priming task, one for each treatment condition. The ten sets of five words were identical across all three conditions with the exception of one word for five of the sentence groupings. For the religious-prime group, five of the sentences contained a religious word: worship, preacher, heaven, devotion, and commandments. The secular-prime group received the same activity except the religious words were replaced with approximate, secular equivalents from the participating secular school's lexicon (e.g., the school's student handbook) that were based on face validity in addition to professional feedback from a social psychologist with expertise in conducting such priming tasks. The secular equivalents for this experiment were honor, leader, success, commitment, and expectations. The secular equivalents were intended to be synonymous words and concepts that are regularly used and incorporated in these students' nonsectarian school environment (i.e., words that are commonly found in their school mission statement, handbook, and rules). The corresponding words for those in the neutral-prime group were eat, path, man, cabbage, and numerous.

\section{Measure of Persistence}

After completing the priming task, participants began the persistence task that consisted of ten anagrams. Participants were asked to unscramble them into actual English words. Four of these words could be unscrambled into English words (tnkoe/token, yncfa/fancy, ruchs/crush, drnba/brand), but the remaining six could not (padus, alavt, dbhoc, vaofea, kylix, malae) (Smith, Kass, Rotunda, \& Scheider, 2006). The amount of time each participant worked on the task before giving up is our measure of persistence. This task served the purpose of exhausting participants' self-regulatory capacities to make it more challenging to exhibit such strength in the final task - deferring gratification with the payout at the end of the experiment (e.g., Rounding et al., 2012).

\section{Measure of Political Tolerance}

For the next section, participants completed a general survey which included a political tolerance scale developed by Sullivan et al. (1982). This section first presented a list of social and political groups "whose beliefs some people oppose." Participants were asked to select the group that they liked least, or, if they could think of another group that they opposed more, to write down the name of that group instead. The modal choice was Neo-Nazis (38\%); Atheists, Fundamentalist Christians, Pro-Life Advocates, Pro-Choice Advocates, Republicans, and members of the Westboro Baptist Church were 
the next most commonly chosen groups (collectively accounting for an additional $46 \%$ of all opposed-group choices). ${ }^{2}$

Participants then answered six Likert-type items that measured their willingness to extend various civil liberties to their least-liked group. Responses were averaged to providing a political tolerance scale score. The items included on the political tolerance scale were:

- [The least-liked group] should be allowed to make a speech in my community.

- A member of [the least-liked group] should be able to run for president.

- [The least-liked group] should be able to hold a rally in public.

- [The least-liked group] should be outlawed.

- Books that are written by [the least-liked group] should be banned from the library.

- I would allow a member of [the least-liked group] to live in my neighborhood.

We also asked an additional Likert-scale item to measure the extent to which participants feel "threatened" by their least liked group to control for this perception when analyzing the impacts of religious and secular cues on political tolerance (see Djupe \& Calfano, 20I2; Eisenstein, 2008; Gibson, 20Io; Sullivan et al., I982).

\section{General Survey}

Participants additionally were asked to provide demographic information in addition to answering survey items that would serve as measures of the effectiveness of the priming treatments. Specifically, participants completed survey items that served as a self-assessment of their sense of religiosity. Since participants experienced the priming task prior to completing the survey, responses to these items serve as measures for whether the priming task had the intended consequence of affecting one's sense of religiosity.

\section{Measure of Delayed-Gratification}

The last portion of the survey thanked participants for taking the time to participate in the study. Participants were then presented with two choices of compensation: receiving an immediate $\$ 5$ upon exiting the study or $\$ 6$ for waiting for their payment until the following week. The decision to receive $\$ 5$ or $\$ 6$ serves as our measure of delayed gratification after having exhausted

2 There were no significant differences across religious, secular, and control conditions in the likelihood of a participant choosing a particular "least-liked group". 
participants' self-regulatory capacities from earlier experimental exercises. Participants who chose to wait a week for $\$ 6$ are considered to have demonstrated a greater willingness to defer gratification (e.g., Rounding et al., 2012). Finally, we asked participants two follow-up questions to probe for whether any participants were aware of the central hypotheses of the study. We ran the analysis with and without participants who exhibited a reasonable amount of suspicion regarding the purpose of our experiment.

\section{Analytic Approach}

We used ordinary least squares and logistic regressions to assess whether priming affected persistence, deferred gratification, and political tolerance. These regression models estimate average differences in the three outcome variables across the three treatment conditions. ${ }^{3}$

Prior to running these models, we conducted two tests to ascertain that our experiment was implemented properly. First, we assessed whether our randomization procedure effectively randomized the treatment that each student participant received. To do this, we ran Kruskal-Wallis tests to see if the participants' observable characteristics differed across the three treatment conditions. If treatment conditions were randomly assigned, we should observe no such differences.

We ran a second test to assess whether our priming techniques had their intended effects. In the general survey that students completed after the treatment, we asked participants several questions about their religiosity. Specifically, participants were asked about their engagement in religious activity as well as the extent to which they felt that religion influenced their everyday choices. Combining responses to these survey items, we constructed a standardized index that indicates an individual's level of religiosity. We then use ordinary least squares to predict individual religiosity using indicator variables for the three treatment groups and other covariates that capture the individual's demographic characteristics. If our priming task worked as intended, then we should observe participants in the religious priming treatment condition to exhibit greater levels of religiosity.

3 Strictly-speaking, it is not necessary to control for individual background characteristics (e.g., gender, grade, race) in our models to the estimate causal effects of each treatment condition because we randomly assigned participants to the treatment conditions. However, we control for them to improve the precision of our estimates. 


\section{Results}

Table I presents the descriptive statistics of the participants as well as shows the effectiveness of the randomization procedure for achieving comparable balances across conditions on observable characteristics. While there appear to be modest differences in the characteristics across the three treatment conditions, none of these differences was found to be statistically significant. Logistic regressions of experimental condition on these covariates suggest that there was no significant differences across treatments ( $p$-values ranging from 0.37 to 0.94 ).

\section{Table 1}

Descriptive Statistics of Study Participants

\begin{tabular}{|c|c|c|c|c|c|c|}
\hline & $\begin{array}{l}\text { Religi } \\
\text { Primi }\end{array}$ & & $\begin{array}{l}\text { Secular } \\
\text { Priming }\end{array}$ & & $\begin{array}{l}\text { Neutral } \\
\text { Priming }\end{array}$ & \\
\hline Population & $\mathrm{N}$ & $\%$ & $\mathrm{~N}$ & $\%$ & $\mathrm{~N}$ & $\%$ \\
\hline Overall & 61 & 34 & 67 & 37 & 52 & 29 \\
\hline \multicolumn{7}{|l|}{ Sex } \\
\hline Male & 31 & 51 & 30 & 45 & 26 & 50 \\
\hline Female & 30 & 49 & 37 & 55 & 26 & 50 \\
\hline \multicolumn{7}{|l|}{ Student's Grade } \\
\hline 11 & 34 & 56 & 42 & 63 & 27 & 52 \\
\hline 12 & 27 & 44 & 25 & 37 & 25 & 48 \\
\hline \multicolumn{7}{|l|}{ Racial Background } \\
\hline Hispanic & 2 & 3 & 1 & 2 & 1 & 2 \\
\hline White & 43 & 72 & 45 & 70 & 39 & 76 \\
\hline American Indian & 1 & 2 & 0 & 0 & 0 & 0 \\
\hline Black & 3 & 5 & 3 & 5 & 1 & 2 \\
\hline Asian & 9 & 15 & 9 & 14 & 6 & 12 \\
\hline Other & 2 & 3 & 6 & 9 & 4 & 8 \\
\hline
\end{tabular}


I66

Journal of Catholic Education / October 2016

Table 2

Effects of Religious and Secular Priming

\begin{tabular}{|c|c|c|c|c|}
\hline & $\begin{array}{c}(1) \\
\text { Religiosity }\end{array}$ & $\begin{array}{c}(2) \\
\text { Persistence } \\
\end{array}$ & $\begin{array}{c}\text { (3) } \\
\text { Gratification }\end{array}$ & $\begin{array}{c}(4) \\
\text { Tolerance }\end{array}$ \\
\hline Religious Priming & $\begin{array}{l}0.53^{* * *} \\
(0.19)\end{array}$ & $\begin{array}{l}-0.30 \\
(0.21)\end{array}$ & $\begin{array}{c}2.05^{*} \\
(0.83)\end{array}$ & $\begin{array}{c}0.28^{*} \\
(0.16)\end{array}$ \\
\hline Secular Priming & $\begin{array}{c}0.31^{*} \\
(0.18)\end{array}$ & $\begin{array}{l}-0.07 \\
(0.16)\end{array}$ & $\begin{array}{c}0.84 \\
(0.33)\end{array}$ & $\begin{array}{c}0.04 \\
(0.15)\end{array}$ \\
\hline \multicolumn{5}{|l|}{ Race/Ethnicity } \\
\hline Hispanic/Latino & $\begin{array}{c}0.38 \\
(0.53)\end{array}$ & $\begin{array}{l}-0.22 \\
(0.32)\end{array}$ & $\begin{array}{c}2.51 \\
(2.51)\end{array}$ & $\begin{array}{l}0.81^{* * *} \\
(0.12)\end{array}$ \\
\hline American Indian & $\begin{array}{l}1.30^{* * *} \\
(0.18)\end{array}$ & $\begin{array}{l}-0.69^{* * *} \\
(0.20)\end{array}$ & $\mathrm{N} / \mathrm{A}$ & $\begin{array}{l}0.78^{* * *} \\
(0.16)\end{array}$ \\
\hline African-American & $\begin{array}{l}-0.07 \\
(0.43)\end{array}$ & $\begin{array}{c}0.24 \\
(0.38)\end{array}$ & $\begin{array}{c}0.46 \\
(0.41)\end{array}$ & $\begin{array}{l}-0.26 \\
(0.52)\end{array}$ \\
\hline Asian & $\begin{array}{c}0.32 \\
(0.19)\end{array}$ & $\begin{array}{l}0.32 \\
(0.23)\end{array}$ & $\begin{array}{c}1.39 \\
(0.66)\end{array}$ & $\begin{array}{l}-0.38^{* *} \\
(0.15)\end{array}$ \\
\hline Other & $\begin{array}{l}-0.30 \\
(0.26)\end{array}$ & $\begin{array}{c}0.03 \\
(0.38)\end{array}$ & $\begin{array}{c}0.52 \\
(0.36)\end{array}$ & $\begin{array}{l}0.67^{* *} \\
(0.31)\end{array}$ \\
\hline Male & $\begin{array}{l}-0.35^{* *} \\
(0.16)\end{array}$ & $\begin{array}{l}-0.00 \\
(0.17)\end{array}$ & $\begin{array}{c}1.11 \\
(0.36)\end{array}$ & $\begin{array}{c}0.21 \\
(0.13)\end{array}$ \\
\hline 12th Grader & $\begin{array}{c}0.18 \\
(0.14)\end{array}$ & $\begin{array}{l}-0.30^{*} \\
(0.17)\end{array}$ & $\begin{array}{l}0.38^{* * *} \\
(0.12)\end{array}$ & $\begin{array}{l}-0.02 \\
(0.15)\end{array}$ \\
\hline Perceived Threat & & & & $\begin{array}{l}-0.42^{* * *} \\
(0.07)\end{array}$ \\
\hline Constant & $\begin{array}{l}-0.24 \\
(0.17)\end{array}$ & $\begin{array}{c}0.22 \\
(0.20)\end{array}$ & $\begin{array}{c}1.71 \\
(0.57)\end{array}$ & $\begin{array}{l}-0.21 \\
(0.18)\end{array}$ \\
\hline$N$ & 174 & 174 & 173 & 173 \\
\hline
\end{tabular}

Note. ${ }^{* *} p<0.01 ;{ }^{* *} p<0.05,{ }^{*} p<0.10$. Coefficient estimates for Religiosity, Persistence, and Political Tolerance are in terms of standard deviations; estimates for Delayed Gratification are in logistic odds ratios. The omitted category for racial background is white. We are unable to obtain a coefficient estimate for the covariate on American Indian in the analysis on Delayed Gratification because of perfect prediction between this observed characteristic and binary outcome. 
As shown in the first column of Table 2, the priming task had its intended effect. The religious priming treatment significantly increased participants' sense of religiosity by $53 \%$ of a standard deviation relative to the control group $(p<$ o.or). The secularized priming also appeared to impact participants' sense of religiosity relative to the control $(p=0.10)$, but the estimated effect was just over half as strong as that of the religious prime. This latter finding could suggest that the use of secularized equivalents to our religious cues potentially conjured a vague sense of religiosity with the participants in that condition.

The results with regard to persistence and deferred gratification are found in columns 2 and 3. Participants spent an average time of II minutes and 45 seconds with the ro anagrams for the persistence task. Time spent on this task was not found to be statistically significant across conditions, suggesting no differences in exhibited persistence on the regulatory-depletion task. However, there were significant differences in participants' choices made with regard to payment preferences at the end of the experiment. The religiouslyprimed participants were more than twice as likely than participants in either the control or secularized groups to defer gratification by opting for the marginally higher, delayed payout $(p=0.08$ and $p=0.03$, respectively). Participants randomly assigned to the secularized-priming condition did not significantly differ from those in the neutral condition with regard to their payout choices.

Religious priming was also found to increase political tolerance. As shown in column 4 , our estimates indicate that participants who received religious cues score $28 \%$ of a standard deviation higher on the political tolerance scale than participants who received neutral cues $(p=0.08)$. Participants primed with religious words also scored $24 \%$ of a standard deviation higher than those from those in the secularized group, but this difference fails to achieve a conventional level of statistical significance $(p=0.15)$. Finally, participants who received secular cues are not statistically distinguishable from those who received neutral cues $(p=0.8 \mathrm{I}) .^{4}$

$4 \quad$ There were 16 participants (9 percent of the students) whose post-experiment responses reflected a reasonable degree of suspicion with regard to the purpose of the tasks. While a participant's knowledge of the purpose of the study could influence their responses, the direction of the bias is uncertain. The results presented are those for the entire sample. However, we have re-run all analyses, excluding participants who expressed some suspicion. Excluding these students has a modest effect on estimates. Excluding suspicious participants increases the estimated impact for the religious prime condition on deferred payout $(p=$ $0.03)$ but attenuates the political tolerance result $(p=0.26)$. 


\begin{abstract}
Discussion
Collectively, these results suggest that neither religious nor secularized cues produce immediate impacts on persistence with our sample. However, after having self-regulatory capacities exhausted from a persistence exercise, participants randomly assigned to the religious priming condition were much more likely to replenish these regulatory capacities as exhibited in their decision to forgo immediate gratification. These positive effects on deferred gratification were not replicated with the secularized equivalents of religious primes. Our findings also suggest that religious cues have a positive impact on political tolerance and, at worst, do not appear to increase intolerance. However, these results were not significantly different than those with the participants in the secularized priming group. Since participants were randomly assigned to one of three treatment conditions, we can be fairly confident that these impacts reflect causal assessments of the independent impacts of religious cues and their secularized equivalents.

These findings could carry important implications for the capacity and ability for religious and nonreligious schools to promote publicly-valued student outcomes. We interpret these results as preliminary evidence to suggest that religious-based education provides benefits that secularized versions cannot replicate. In particular, the overt religious component of Catholic schools (and, more broadly, religious schools) that is constitutive of their organizational identity appears to independently contribute to their effectiveness by exerting a positive influence on self-regulatory behaviors in terms of facilitating the replenishment of exhausted self-regulatory capacities. Given this causal relationship, in addition to the strong association between this noncognitive skill and academic outcomes such as high school degree attainment and college matriculation found in prior studies, there is reason to believe that the religious component of faith-based schools has a positive, independent effect on publicly-valued educational outcomes.

Many high-achieving public charter schools are modeled after Catholic schools but are legally required to omit any sort of explicit religious component. While this exclusion would seemingly have no effect on these schools' abilities to match the successes of Catholic and other faith-based schools, our results, paired with findings from recent charter school studies, should raise questions with regard to this assumption. Specifically, students who win lotteries to attend oversubscribed charter schools in Boston have shown remarkable increases in measures of cognitive achievement (e.g., SAT scores, standardized test scores) relative to their public school peers. Yet thus far, there
\end{abstract}


is no evidence that these charter schools produce equally sizeable effects in terms of rates of high school graduation and college enrollment (Angrist, Cohodes, Dynarksi, Pathak, \& Walters, 20I6). These results are in stark contrast to the earlier-cited literature on Catholic schools' successes that tend to exhibit better outcomes with regard to educational attainment. While there are a number of plausible explanations for such differences, our findings may imply that the regular activations of students' religious conceptualizations can play an important role in enhancing these outcomes.

The evidence that religion can assist in the promotion of publicly-valued educational outcomes is perhaps valuable in itself, but the findings concerning tolerance could also help to alleviate apprehensions regarding plausible drawbacks of faith-based education. Religion is often assumed to be a source of or justification for intolerance, but our results corroborate the results of earlier works that find religion in education contexts to potentially supply the moral capital and to foster dispositions that facilitate tolerance (e.g., Bellah et al., I985; Eisenstein, 2008). It is again worth noting that effects with secularized primes were not significantly different from religious primes on this outcome. This latter finding possibly implies that increasing tolerance can be accomplished by activating a student's moral sense, but this activation does not necessarily require religious conceptualizations. However, regardless of whether this particular result is replicable with secularized equivalents, the effects from this aspect of the study potentially refute the assertion that religion has an independent, negative effect on tolerance.

Finally, our findings speak to an important trend in Catholic schools that could possibly be remediated through policy. Many schools have closed over the past 50 years, and others have converted to public charter status as a means for preservation. Results of this study raise important issues pertaining to school choice policy and difficult choices that many religious school administrators increasingly face with regard to the decision to convert to charter school status. In particular, although endorsing the expansion of charter schools over policies that enable religious school choice is likely a politically solvent strategy, it could come at the cost of potential gains with regard to self-regulation and other noncognitive skills that are important for educational attainment, success in the labor-market, and other positive life outcomes (Almlund et al., 20II). Moreover, while an individual school may retain a great deal of its identity in terms of personnel and student population after its conversion to charter status, the loss of overt religious cues that comes with this conversion may inhibit their abilities to continue facilitating such outcomes. 


\section{Limitations}

The sample for this study consisted of predominantly white, higherachieving IIth- and I2th-grade students from a southern U.S. state. Though we have posited what our findings could mean for Catholic as well as other religious schools, we must be careful not to overstate their conclusiveness. Conducting an experiment in a highly-controlled, laboratory setting lends confidence that the results are directly caused by the differences in treatment conditions; however, our homogenous sample likely limits the extent to which we can generalize these findings with much confidence (e.g., we do not know whether and the extent to which these findings would occur with elementary school students as well as those who reside in urban communities) (Levitt \& List, 2007).

That being said, the use of controlled, laboratory experiments has become an increasingly popular method for developing policy-relevant hypotheses to incorporate in field experiments (Bowen, Buck, Deck, Mills, \& Shuls, 2015; Hastings \& Weinstein, 2008; Perez, 20II). We encourage researchers to consider how tests similar to the one we have conducted can be implemented in contexts to provide greater generalizability to a broader population of students in conditions that more closely reflect their everyday lives in school. Such scholarly pursuits would be valuable for better understanding issues and informing the debate regarding the place of religious schools in civil society.

It is also worth noting that these findings pertain to a fairly narrow aspect of faith-based education. We do not wish to convey the notions that religious schools are essentially identical to public schools with the exception of overt religious words and symbols and that this component is the lynchpin of their successes. The extent to which the religious cues that we have embedded into our experiment mimic religious activations that occur in more natural school settings requires further investigation. One-time religious activations are substantively different from being in an environment permeated by a religious ethos. It may be possible that more-regular religious activations that occur in faith-based schools lead to more-pronounced effects, or it might be the case that such influences attenuate with increased exposure. However, by examining this particular aspect of religious schools, we hope that these results can further inform the larger investigation for determining the roles that various components, practices, and contexts, play with regard to how these schools positively impact student development. 


\section{Conclusion}

The results of this study raise important considerations when assessing claims about the value of the explicitly religious component of faith-based education. There seems to be something unique about religious, particularly Catholic, schools that cannot be fully captured with secularized replicas. Specifically, the evidence from this study suggests that religious schools provide environments that are likely to activate conceptualizations that enable students to more effectively replenish their self-regulatory capacities as exhibited in the ability to defer the need for more-immediate gratification, a skill commonly found to translate into greater educational attainment. In conjunction with the benefits to Catholic and other faith-based schooling, concerns have arisen with regard to the possibility that religion facilitates negative effects pertaining to the growth and development of civic values. Our preliminary results suggest that the priming effects from religious cues in these settings positively impacts self-regulation and does not further affect the development of political intolerance.

Although we believe this study helps to reveal reasons for the effectiveness of Catholic schools with regard to outcomes pertaining to educational attainment, additional studies are still needed to further investigate the mechanisms by which religious cues produce these effects. For example, do cues activate previously learned Judeo-Christian values that emphasize benefits that often come from deferring instant gratification in the present for greater rewards in the future? Addressing this question and others that help to explain the mechanisms behind this process would help determine how to best make use of these cues. Replications or even field tests to explore the extent to which such effects can or cannot be emulated in secular contexts would speak further to the generalizability of our results. However, our findings seem to lend credibility to the claim that the overtly religious component of Catholic and religious schools can facilitate nontrivial, publiclyvalued benefits to students without necessarily fostering commonly-perceived drawbacks that pertain to the development of civic values. 


\section{References}

Almlund, M., Duckworth, A. L., Heckman, J., \& Kautz, T. D. (2oII). Personality psychology and economics. In E. A. Hanushek, S. Machin, \& L. Woessmann (Eds.), Handbook of the Economics of Education (pp. I-I8I). Amsterdam: Elsevier.

Altonji, J. G., Elder, T. E., \& Taber, C. R. (2005). Selection on observed and unobserved variables: Assessing the effectiveness of Catholic schools. Journal of Political Economy, IIJ (I), I5I-I84. doi: I0.3386/w783I

Angrist, J. D., Pathak, P. A., Cohodes, S. R., Dynarksi, S. M., \& Walters, C. R. (2016). Stand and deliver: Effects of Boston's charter high schools on college preparation, entry, and choice. Journal of Labor Economics, 34(2), 275-318. doi: 10.3386/w19275

Banks, J. (200I). Cultural diversity and education: Foundations, curriculum, and teaching. Needham Heights, MA: Pearson Education.

Bargh, J. A., \& Chartrand, T. L. (20I4). The mind in the middle: A practical guide to priming and automaticity research. In H. T. Reis \& C. M. Judd (Eds.), Handbook of research methods in social and personality psychology (pp. 3II-344). New York, NY: Cambridge University Press.

Baumeister, R. F., \& Heatherton, T. F. (1996). Self-regulation failure: An overview. Psychological Inquiry: An International Journal for the Advancement of Psychological Theory, 7(I), I-I5. doi: I0.I207/si5327965plio7oI I

Baumesiter, R. F., \& Vohs, K. D. (2004). Self-regulation. In C. Peterson \& M. E. P. Seligman (Eds.), Character strengths and virtues: A handbook and classification (pp. 499-516). Washington, DC/New York, NY: American Psychological Association/Oxford University Press.

Bellah, R. N., Madsen, R., Sullivan, W. S., Swidler, A., \& Tipton, S. M. (1985). Habits of the heart: Individualism and commitment in American life. Berkeley, CA: University of California Press.

Bembenutty, H., \& Karabenick, S. A. (2004). Inherent association between academic delay of gratification, future time perspective, and self-regulated learning. Educational Psychology Revieww, 16(I), 35-57. doi: I0.1023/b:edpr.00000I2344.34008.5c

Bering, J. M., \& Johnson, D. (2005). "Oh, Lord...you perceive my thoughts from afar": Recursiveness and the evolution of supernatural agency. Journal of Cognition and Culture, 5(I/2), II8-I42. doi: I0.II63/I568537054068679

Boffetti, J. (200I). All schools are public schools. Washington DC: Faith and Reason Institute.

Bowen, D. H., Buck, S., Deck, C., Mills, J. N., Shuls, J. V. (2015). Risky business: An analysis of teacher risk preferences. Education Economics, 23(4), 470-480. doi: I0.1080/09645292.20I4.966062

Braun, H., Jenkins, F., \& Grigg, W. (2006). Comparing private schools and public schools using bierarchical linear modeling (NCES 2006-46r). U.S. Department of Education, National Center for Education Statistics, Institute of Education Sciences. Washington, DC: U.S. Government Printing Office.

Brinig, M. F., \& Garnett, N. S. (20I4). Lost classroom, lost community: Catholic schools' importance in urban America. Chicago, IL: The University of Chicago Press.

Bryk, A. S., Lee, V. E., \& Holland, P. B. (1993). Catholic schools and the common good. Cambridge, MA: Harvard University Press. 
Campbell, D. E. (200I). Bowling together: Private schools, public ends. Education Next, I(3), 55-6r.

Carter, E. C., McCullough, M. E., \& Carver, C. S. (20I2). The mediating role of monitoring in the association of religion with self-control. Social Psychological and Personality Science, 3(6), 69I-697. doi: Io.II77/I9485506I2438925

Center for Research on Education Outcomes. (2013). National charter study 20I3. Stanford, CA: Stanford University.

Cheng, A. (20I4). Does Homeschooling or private schooling promote political intolerance? Evidence from a Christian university. Journal of School Choice, 8(I), 49-68. doi: Io.I080/I5582I59.20I4.8754II

Chubb, J. E., \& Moe, T. M. (1988). Politics, markets, and the organization of schools. The American Political Science Review, 82(4), 1065-1087. doi: 10.2307/1961750

Coleman, J. S., \& Hoffer, T. (1987). Public and private high schools. New York, NY: Basic Books.

Coleman, J., Hoffer, T., \& Kilgore, S. (1981). Public and private schools: An analysis of High School and Beyond: A national longitudinal study for the rg8os (NCES Report 300-780208). Washington, DC: National Center for Educational Statistics.

Djupe, P. A., \& Calfano, B. R. (20I2). Religious value priming, threat, and political tolerance. Political Research Quarterly, 66(4), 768-780. doi 10.1177/1065912912471203

Eide, E. R., Goldhaber, D. D., \& Showalter, M. H. (2004). Does Catholic high school attendance lead to attendance at a more selective college? Social Science Quarterly, 85(5), I335-I352. doi: Io.IIII/j.0038-494I.2004.00279.X

Eisenstein, M. A. (2008). Religion and the politics of tolerance: How Christianity builds democracy. Waco, TX: Baylor University Press.

Erickson, L. D., \& Phillips, J.W. (2012). The effect of religious-based mentoring on educational attainment: More than just a spiritual high? Journal for the Scientific Study of Religion, ${ }_{51}(3)$, 568-587. doi: $10.11 I I /$ j.I468-5906.20I2.0166r.X

Evans, W. N., \& Schwab, R. M. (1995). Finishing high school and starting college: Do Catholic schools make a difference? The Quarterly Journal of Economics, IIO(4), 941-974. doi: $10.2307 / 2946645$

Figlio, D. N., \& Stone, J. A. (2000). Are private schools really better? Research in Labor Economics, I8, II5-I40. doi: I0.I0I6/soI47-9I2I(99)I802I-X

Finn, Jr., C. E., \& Smarick, A. (2009, April 2I). Our endangered Catholic schools. The Washington Post. Retrieved from http://www.washingtonpost.com/wp-dyn/content/ article/2009/04/20/AR2009042002816.html

Fishbach, A., Friedman, R. S., \& Kruglanski, A. W. (2003). Leading us not into temptation: Momentary allurements elicit overriding goal activation. Journal of Personality and Social Psychology, 84(2), 296-309. doi: $\underline{10.1037 / 0022-3514.84 .2 .296}$

Fleming, D. J., Mitchell, W., \& McNally, M. (20I4). Can markets make citizens? School vouchers, political tolerance, and civic engagement. Journal of School Choice, 8(2), 213-226. doi: $\underline{10.1080 / 15582159.2014 .905397}$

Gamoran, A. (1996). Student achievement in public magnet, public comprehensive, and private city high schools. Educational Evaluation and Policy Analysis, I8(I), I-I8. doi: I0.3102/0162373701800100I 
Geyer, A. \& Baumeister, R. F. (2005). Religion, morality, and self-control: Values, virtues, and vices. In R.F. Paloutzian, \& C.L. Park (Eds.), Handbook of Psychology of Religion and Spirituality (pp. 412-432). New York, NY: Guilford Press.

Gibson, J. L. (20IO). The political consequences of religiosity: Does religion always cause political intolerance? In A Wolfe, \& I. Katznelson (Eds.), Religion and democracy in the United States: Danger or opportunity? (pp. I47-I75). Princeton, NJ: Princeton University Press.

Godwin, R. K., \& Kemerer, F. R. (2002). School choice tradeoffs: Liberty, equity, and diversity. Austin, TX: University of Texas Press.

Gradstein, M., \& Justman, M. (2005). The melting pot and school choice. Journal of Public Economics, 89(5/6), 871-896. doi: 10.1016/j.jpubec0.2004.05.007

Greene, J. P, Mellow, N., \& Giammo, J. (1999). Private schools and the public good. Catholic Education: A Journal of Inquiry and Practice, 2(4), 429-443.

Grogger, J., \& Neal, D. (2000). Further evidence on the effects of Catholic secondary schooling. Brookings-Wharton Papers on Urban Affairs, 151-20I. doi: 10.1353/ urb.2000.0006

Gutmann, A. (1987). Democratic education. Princeton New Jersey: Princeton University Press.

Gutmann, A. (1995). Civic education and social diversity. Ethics, I05(3), 557-579. doi: I0.1086/293727

Hall, D. L., Matz, D. C., \& Wood, W. (2oro). Why don't we practice what we preach? A meta-analytic review of religious racism. Personality and Social Psychology Review, I4(I), I26-I39. doi: I0.II77/IO 88868309352179

Harrison, J., \& McKay, R. T. (2013). Do religions and moral concepts influence the ability to delay gratification? A priming study. Journal of Articles in Support of the Null Hypothesis, IO (I), 25-40.

Hastings, J. S., \& Weinstein, J. M. (2008). Information, school choice, and academic achievement: Evidence from two experiments. The Quarterly Journal of Economics, I23(4), I373-I4I4. doi:_o.II62/qjec.2008.I23.4.I373

Hoffer, T. (1997). Effects of Catholic school attendance on student achievement: A review and extension of research. Journal of Catholic Education, I(2), 212-235.

Hoffer, T., Greeley, A. M., \& Coleman, J. S. (1985). Achievement growth in public and Catholic schools. Sociology of Education, 58(2), 74-97. doi: 10.2307/2112249

Hunter, J. D. (200I). The death of character: Moral education in an age without good or evil. New York, NY: Basic Books.

Jeynes, W. H. (2012). A meta-analysis of the effects and contributions of public, public charter, and religious schools on student outcomes. Peabody Journal of Education, 87(3), 305-335. doi: 10.1080/0161956X.2012.679542

Johnson, M. K., Rowatt, W. C., \& LaBouff, J. (2010). Priming Christian religious concepts increases racial prejudice. Social Psychological and Personality Science, I(2), II9-I26. doi: Io.II77/1948550609357246

Kennedy, S. (20I2, October 5). Charting a future for Catholic education. City Journal. Retrieved from http://www.city-journal.org/2oI2/eonIoIssk.html 
Kim, M., \& Placier, M. (2004). Comparison of academic development in Catholic versus non-Catholic private secondary schools. Educational Policy Analysis Archives, I2(5). Retrieved from http://epaa.asu.edu/ojs/article/view/16I/287

Kim, Y. J. (20II). Catholic schools or school quality? The effects of Catholic schools on labor market outcomes. Economics of Education Review, 30(3), 546-558. doi:Io.IoI6/j. econedurev.2010.12.007

Levitt, S. D., \& List, J. A. (2007). What do laboratory experiments measuring social preferences reveal about the real world? The Journal of Economic Perspectives, 2I, I53-I74. doi: $10.1257 /$ jep.21.2.153

Lubienski, S. T., \& Lubienski, C. (2006). School sector and academic achievement: A multilevel analysis of NAEP mathematics data. American Educational Research Journal, 43(4), 65I-698. doi: $10.3102 / 0002831204300465 \mathrm{I}$

Macedo, S. (2003). Diversity and distrust: Civic education in a multicultural society. Cambridge, MA: Harvard University Press.

McCullough, M. E. \& Willoughby, B. L. B. (2009). Religion, self-regulation, and selfcontrol: Associations, explanations, and implications. Psychological Bulletin, I35(I), 69-93. doi: $10.1037 /$ aooI 4213

McShane, M. Q. \& Kelly, A. P. (20I4). Sector switchers: Why Catholic schools convert to charters and what happens next. Indianapolis, IN: The Friedman Foundation for Educational Choice.

Meyer, P. (2007). Can Catholic schools be saved? Education Next, 7(2), I2-20.

Mischel, W., Shoda, Y., \& Rodriguez, M. L. (1989). Delay of gratification in children. Science, 244(4907), 933-938. doi: 10.II26/science.2658056

Neal, D. (1997). The effect of Catholic secondary schooling on educational attainment. Journal of Labor Economics, I5(I), 98-I23. doi: I0.3386/W5353

Nguyen, A. N., Taylor, J., \& Bradley, S. (2006). The estimated effect of Catholic schooling on educational outcomes using propensity score matching. Bulletin of Economic Research, 58(4), 285-307. doi: I0.IIII/j.0307-3378.2006.00245.x

Nunn, C. Z., Crockett, H. J., \& Williams, J. A. (1978). Tolerance for nonconformity. San Francisco, CA: Jossey-Bass.

Öner-Özkan, B. (2007). Future time orientation and religion. Social Behaviour and Personality: An International Journal, 35(I), 5I-62. doi: 10.2224/sbp.2007.35.I.5I

Perez, M. C. (20II). Inequity aversion differences: Experimental evidence among prospective teachers and lawyers. doi: 10.2139/ssrn.2018697

Pichon, I., Boccato, G., \& Saroglou, V. (2007). Nonconscious influences of religion on prosociality: A priming study. European Journal of Social Psychology, 37, IO32-I045. doi: IO.IO02/ejsp.4I6

Rachlin, H. (2000). The science of self-control. Cambridge, MA: Harvard University Press.

Rounding, K., Lee, A., Jacobson, J. A., \& Ji, L. (20I2). Religion replenishes self-control. Psychological Science, 23(6), 635-642. doi: Io.II77/09567976II43I987

Sander, W., \& Krautmann, A. C. (1995). Catholic schools, dropout rates, and educational attainment. Economic Inquiry, 33(2), 217-233. doi:I0.IIII/j.I465-7295.I995.tboI858.x 
I76 Journal of Catholic Education / October 2016

Scott, L. A., Rock, D. A., Pollack, J. M., Ingels, S. J. (1995). Two years later: Cognitive gains and school transitions of NELS: 88 eighth graders (NCES Report 95436). U.S. Department of Education, Office of Educational Research and Improvement. Washington, DC: U.S. Government Printing Office.

Segal, C. (2008). Classroom behavior. Journal of Human Resources, 43(4), 783-814. doi: 10.3368/ jhr. 43.4 .783

Shariff, A. F., \& Norenzayan, A. (2007). God is watching you: Priming God concepts increases prosocial behavior in an anonymous economic game. Psychological Science, I8(9), 803-809. doi: I0.IIII/j.I467-9280.2007.0I983.X

Short, G. (2002). Faith-based schools: A threat to social cohesion? British Journal of Religious Education, 25(2), I29-I4I. doi: 10.IIII/I467-9752.00295

Smith, S. A., Kass, S. J., Rotunda, R. J., \& Schneider, S. K. (2006). If at first you don't succeed: Effects of failure on general and task-specific self-efficacy and performance. North American Journal of Psychology, 8, I7I-182. doi: 10.1037/0021-9010.73.2.208

Sullivan, J. L., Piereson, J., \& Marcus, G. E. (1982). Political tolerance and American democracy. Chicago, IL: University of Chicago Press.

Toburen, T., \& Meier, B. P. (2010). Priming god-related concepts increases anxiety and task persistence. Journal of Social and Clinical Psychology, 29(2), I27-I43. doi: I0.I52I/ jscp.2010.29.2.127

Uhlmann, E. L., Poehlman, T. A., Tannenbaum, D., Bargh, J. A. (20II). Implicit Puritanism in American moral cognition. Journal of Experimental Social Psychology, $47(2), 312-320$. doi:Io.IoI6/j.jesp.2010.10.013

Whitman, D. (2008). Sweating the small stuff: Inner-city schools and the new paternalism. Washington, DC: Thomas B. Fordham Institute

Wilcox, C., \& Jelen, T. (1990). Evangelicals and political tolerance. American Politics Quarterly, I8(I), 25-46. doi: I0.II77/I532673X900I800102

Wolf, P. J. (2005). School choice and civic values. In J.R. Betts \& T. Loveless, Getting school choice right: Ensuring equity and efficiency in education policy. Washington, DC: Brookings Institution Press.

Wolf, P. J. (2014). The school choice research-program nexus: Why we know so little about school choice best practices. In M.Q. McShane (Ed.), New and better schools: The supply side of school choice (pp. 209-234). Lanham, MD: Rowman \& Littlefield.

Daniel H. Bowen is an assistant professor with the Department of Education Administration and Human Resource Development at Texas AESM University. For correspondence regarding this article, he can reached at dhbowen@tamu.edu

Albert Cheng is a postdoctoral research fellow with the Program on Education Policy and Governance at Harvard University and an affliated researcher at Charassein: The Character Assessment Initiative. 